UDK 811.161 .2

DOI $10.15421 / 462001$

\title{
DISCOURSE DIRECTION OF RESEARCH OF ARTISTIC TEXT IN MODERN LANGUAGE UKRAINIAN STUDIES
}

N. Holikova

Associate Professor, Doctor of Philology, Professor of the Department of Ukrainian Language,

Oles Honchar Dnipro National University nataliaholikova62@gmail.com orcid.org/0000-0003-4157-1275

Introduction. In the linguistics of the late XX - early XXI century, language is increasingly seen as a dynamic phenomenon, which is the most active form of communication in any sphere of public life. The traditional study of systemic connections between lingual units of different levels is gradually undergoing a theoretical and conceptual reorientation in the direction of scientific development of the "humanization" of language, which has always been relevant in the history of philosophy and other humanities. Recently, new and non-trivial problems have been the subject of study, and within linguistics the number of works devoted to the role of language in the formation of the cultural-semiotic component of social consciousness is rapidly increasing. The interests of researchers, - notes K. Serazhym, - "shifted from the structural description of language to the study of the historical context in which language develops and functions" (Serazhym, 2010: 9). It is no coincidence that in modern linguistics the decisive place belongs to human space. According to F. Batsevych, O. Revzina, it is constituted by individuals who, communicating with each other, perform appropriate communicative, social, interpersonal, ideological, psychological roles (Batsevich, 2006: 35; Revzina, 2004: 12).

One of the main issues of linguo-Ukrainian studies is a comprehensive study of the concept of discourse, which reflects a variety of real manifestations of human language communication in certain social spheres of its communicative space. The actualization of this concept in various scientific fields, the representatives of which study the essence and mechanisms of interaction of constants of such linguistic and philosophical dichotomies as "language and society", "language and man", has led to the need for its clear definition and typology of discourses, etc. Despite the fact that linguists use a number of methods of discursive analysis of linguistic units, there is currently no single approach to their study within the theory of discourse.

The purpose of our study is to identify and substantiate the features of the literary text in terms of modern discourse. The main objectives of the article: to determine the typological and categorical features of artistic discourse, to establish and describe the most important aspects of the study of artistic texts of different genres within discourse.

Methods and methodology of investigation. The paper uses general scientific methods of observation, analysis, synthesis, comparison; linguistic methods, including the descriptive methodto interpret the discursive status of the literary text; the method of integrative analysis, which is the basis of a comprehensive study of a set of different aspects used in the study of the literary text as the embodiment of individual-authorial communicative intentions; the contextual-interpretive method - to identify probable reading strategies of reception of the literary text and its components.

Results and discussion. Many modern researchers, considering the concept of discourse, primarily turn to the explanation of the semantics and etymology of the word that nominates it, as well as to the historical origins of the interpretation of the analyzed concept.

In linguistic practice, there are common word usages that differ in emphasis - dIscourse and discOUrse, the first of which is associated with a metaphorical rethinking of one of the meanings of the Latin word discursus, meaning "movement (thought, movement, logical progressive development of thought)"; in the internal form of the second phonetic variant of the word discourse the lexical meaning "conversation, conversation" is actualized. The most lexical-semantic variant of 


\section{Ukrainian sense. 2020. ISSN 2313-4437}

the word discourse is borrowed from the French language, in which it means any dialogical communication. Thus, the concept of discourse in the broadest sense is associated with all manifestations of communication. According to O. Selivanova, discourse is a consequence of modeling knowledge structures that provide strategic planning, flow and control of communication, the mechanisms of communicative competence, regulation of interactivity processes, etc. [Selivanova, 2008: 611].

An important communicative-semantic segment of the holistic nature of the analyzed concept is its interaction with various factors that reflect the essence of communication, in particular with the concept of the text. It is known that the introduction of the term discourse into scientific circulation is associated with the name of $\mathrm{Z}$. Harris, who in the middle of the twentieth century (1952) used this word in the analysis of the language of advertising. Instead, only in the early 70's of the twentieth century there was a problem of isolation and theoretical substantiation of the concept of "discourse" in connection with the formation of a new linguistic direction - the linguistics of the text. At that time, "there was a need for a clear delineation of the subject of study of the linguistics of the text, and hence a clear definition of the essence of two key concepts - the text and discourse" (Serazhim, 2010: 10). E. Benvenist was the first to formulate the main difference between them: discourse - the process of applying the language system, and the text the result of this process. The researcher's view, inspired by the anthropocentric paradigm of language, later made it possible to consider discourse in science as "the functioning of language in living communication" as "speech appropriated by the speaker" (Benveniste, 1959).

Recently, the dichotomy "text" - "discourse" is actively studied by linguists, who identify all aspects that allow a comprehensive description of the communicative intentions of the text and its components. Scholars often express similar views, defining discourse in its relation to the text. For example, N. Arutyunova notes: "Discourse is a coherent text together with extralinguistic pragmatic, socio-cultural, psychological and other factors; the text taken in the event aspect; speech, which is considered as a purposeful social action, as a component that is a participant in the interaction of people and the mechanisms of their consciousness (cognitive processes). Discourse is a speech "immersed in life" (Arutyunova, 1990: 136-137). Yu. Stepanov also qualifies discourse as a "submerged text" (Stepanov, 1997: 110). FS Batsevych connects the written form of discourse with the concept of text, which appears as "exhausted", "stopped" discourse (Batsevych, 2011: 25), K. Serazhym considers discourse as a complex sociolinguistic phenomenon of the modern communicative environment, which, in particular, has a "visible" - linguistic (coherent text or its semantically significant and syntactically complete fragment) and "invisible" - extralinguistic (knowledge of the world, thoughts, guidelines, purpose of the addressee) structure, characterized by the commonality of the world "built" during development of the discourse by the author and interpreted by his listener or reader (Serazhym, 2010: 12-13), etc.

The linguistic tradition still has a great influence on the development of theoretical principles of categorization and typology of the concept of discourse, because until recently the discourse was often identified with the text as a complex linguistic sign that arises as a result of the process of language formation. Currently, researchers outline the structural and semantic parameters of the text with a number of features that also appear relevant and objective for the discourse: completeness; coherence; integrity; lexical, grammatical, logical, stylistic, semantic coherence; compositional completeness; communicative and pragmatic orientation, etc. Because of this, some linguists suggest that under certain conditions the text is a discourse. In particular, O. Perelomova notes: "Linguistic study of a text, the task of which is to identify not only the linguistic inventory, but also the ratio of linguistic and extralinguistic factors in the creation of a language work, is multifaceted. One of the directions of such analysis is the theory of discourse" (Perelomova, 2007: 95). However, the rapid development of discourse theory in linguistics in the late twentieth - early twenty-first century caused an urgent need to distinguish the essence of the analyzed concepts, to identify and scientifically substantiate their features.

Drawing a "boundary" between text and discourse, linguists explain the specifics and mechanism of correlation of these concepts in different ways. We accept the conclusions of 


\section{Ukrainian sense. 2020. ISSN 2313-4437}

researchers, in whose works the dichotomy "text" - "discourse" is based on the opposition of the relevant features "dynamism" - "static". For example, O. Kubryakova believes that functional orientation and communicative-pragmatic efficiency are important for discourse; the text has a symbolic (semiotic) character, its main features are informational self-sufficiency, purposefulness, length (Kubryakova, 2004: 510-515).

V. Karasyk and A. Prykhodko comment on the text - discourse correlation in a slightly different way. V. Karasyk models the interaction of text and discourse as "process - result": discourse is a text immersed in a situation of communication, or it is communication with the help of a text (Karasyk, 2007: 278). A. Prykhodko sees a hypo-hyperonymic correlation between the outlined concepts: the text serves as a constitutive foundation for the discourse, the discourse in turn is built on it and has the opportunity to expand over all available texts (Prykhodko, 2008: 38).

Differentiation of discourses is one of the most important issues of modern discourse, which is currently a problem that researchers, based on a wide range of different socio-linguistic manifestations of communication, solve differently. Studying discourse as a sociolinguistic phenomenon, K. Serazhym explains: "The diversity of communicative situations in which discursive activity takes place, generates, respectively, the types of diversity of discourses" (Serazhym, 2010: 49). The researcher, like many other linguists who joined the theoretical generalization of science, emphasizes the lack of common criteria for classifying discourses, which led to the selection of their various types: pedagogical discourse, parental discourse, ethical discourse, religious discourse, scientific discourse, scientific discourse discourse, administrative discourse, business discourse, legal discourse, military discourse, sports discourse, medical discourse, advertising discourse, mass discourse (Serazhim, 2010: 49-50). G. Pocheptsov proposes to distinguish the following types of discourses: TV and radio discourse, newspaper, film discourse, political, unofficial, untrue, offensive, folklore, theatrical, literary (poetic), entertaining, totalitarian, religious, ritual, ceremonial, ceremonial, mythological (Pocheptsov, 1982: 55).

These and many other classifications of discourses, developed in the works of modern linguists, show too broad an understanding of the concept of "discourse", which, accordingly, can be implemented in any social sphere, in various life situations. We agree with the opinion of those researchers who propose to first distinguish between oral and written discourses and study them using the method of communicative transaction: "acoustic channel - oral discourse, visual channel - written discourse" (Pocheptsov, 1982: 33). The study of, in particular, written discourse makes it possible to actualize the conceptual opposition "text" - "discourse".

To establish a typology of discourses, as well as texts, it is necessary to develop common criteria for their classification and determine the main categories of text and discourse. In particular, $\mathrm{N}$. Kondratenko notes that among the priority areas of text and discourse-centric research an important role belongs to the creation of a typology of categories of the subject of study. It distinguishes three groups of such categories: main, in-text and out-of-text. The researcher includes informativeness and communicativeness as the main categories. In-text categories, in her opinion, are directed inside the text and are characterized by coherence, integrity, and articulation. External text categories make it possible to interpret the text as an element of verbal communication between speakers and between texts. This group includes referentiality, intersubjectivity and intertextuality (Kondratenko, 2015: 6). Such textual-typological categories are to some extent reflected in discursive categories, which sometimes coincide with each other, but mostly create a background for defining specific features and establishing criteria for classifying discourses.

The analysis of artistic texts in the plane of discourse and anthropocentrism can be successfully carried out taking into account the communicative strategies of those communicators who initiate the communication itself. This role is played by writers who, creating an artistic text for readers, predict the nature and direction of the communicative act between the sender and the addressees. Thus, in this case, an important discursive category is targeting. In our opinion, the definition of typological status for artistic discourse is primarily based on the criterion of addressee orientation, which was substantiated by V. Karasyk (Karasyk, 2007). The researcher singled out personality-oriented (personal) and status-oriented (institutional) discourses. In the first type, the 


\section{Ukrainian sense. 2020. ISSN 2313-4437}

speaker appears as a person, in the second - as a representative of a certain society (Karasyk, 2002: 17). Personal discourse, in particular, in the classification of V. Karasyk is represented by two varieties - existential and domestic. Of these two types of personality-oriented discourse, the existential itself is based on literary language, which in the literary text conveys aesthetic tastes, all the beauty of the author's word, because the writer - the addressee - acts as a person in all the richness of his inner world. views in the statements: "Existential communication is mainly monologue and is represented by works of fiction and philosophical and psychological retrospective texts" (Karasyk, 2002: 11).

In addition, artistic discourse is distinguished based on such criteria as stylistic differentiation (Gocinetc, 2010; Korolyova, 2016), the sphere of functioning (Belova, 2002). According to G. Pocheptsov's classification, it belongs to the unaddressed subtype of the written type of discourses (Pocheptsov, 1982).

In our opinion, artistic discourse as one of the most complex fragments of common language communicative space should be qualified, first of all, taking into account the peculiarities of "communication" of the addressee with recipients, the role of the first of which is decisive because the author "initiates" - speech activity of communicators. Thus, in the branched grid of coordinates (sphere of communication, social and communicative parameters, stylistic differentiation, genre affiliation, etc.), according to which numerous discourses are classified, artistic discourse belongs to the personal-existential type.

In the context of a multifaceted interpretation of the concept of literary text, recorded in the research of modern linguists, the scientific concept of the dichotomy "text" - "discourse", developed by many domestic and foreign linguists, is also highlighted (Aznaurova, 1988; Batsevich, 2009; Bogdanov, 1993; Zagnitko, 2008; Kondratenko, 2015; Serazhym, 2010, etc.), to argue the need to collectively qualify prose, poetic, dramatic works as a holistic artistic discourse, which provides a new - intentionally receptive - approach to the interpretation of the writer's language in various linguistic fields. It is known that the literary text as a process and result of the speech activity of the author (addressee), which should be perceived and evaluated by readers (addressees), has been the object of special scientific research only since the second half of the twentieth century. Currently, there are several approaches to its study: linguocentric, text-centric, anthropocentric, cognitive (Babenko \& Karazin, 2004: 15). According to N. Kondratenko, the introduction of the literary text in the field of anthropocentric, cognitive, communicative, pragmatic analysis gave the artistic text a discursive status, which takes into account not only the immanent textual parameters of the prose writer, but also pragmatic guidance of the speaker (author) and ways to decipher it (Kondratenko, 2015: 62).

Despite the fact that the distinction between the concepts of "artistic text" / "artistic discourse" is a debatable issue of modern linguistics, during the 90s of the twentieth century - the beginning of the XXI century scholars are increasingly analyzing the very artistic discourses of many writers. The authors of dissertations in recent years propose to distinguish between prose (Blinov, 2011), poetic (Ogar, 2014; Tsolin, 2016) and dramatic (Korolyova, 2017) discourses. In their research, the concept of prose discourse is postulated by such representatives of the Kharkiv School of Linguistics as I. Kolegaeva (2010), I. Frolova, O. Ometsynska (2018), etc., who mostly identify it with the concept of artistic discourse. In particular, I. Kolegaeva emphasizes that within the artistic discourse it is expedient to distinguish two basic subtypes: prose and poetic; "Secondary or fictitiousness is inherent mainly in prose artistic discourse, where the speech of the characters is a communicative-secondary activity" (Kolegaeva, 2010: 103). In general, artistic discourse is characterized by such categories as addressability, expressiveness, emotionality, interpretability, intertextuality, cohesion, coherence, communicativeness, and so on.

Artistic discourse, in contrast to other discourses, involves indirect communication of the author (addressee) with numerous readers (addressees). When creating a text, the writer predicts the expected reaction to its content from readers, instead of "translating" the literary text into discourse, the recipients carry out in their own way, based on their own knowledge, experience, feelings and emotions. The interaction of the addressee author with numerous addressees is devoid of real 


\section{Ukrainian sense. 2020. ISSN 2313-4437}

communicative factors, in particular temporal and local fixation. Despite the lack of direct contact, the writer's communicative influence on readers is obviously effective: if the artist has a deep knowledge of language, individualizes and emphasizes linguistic means, it causes a certain attitude to his literary texts and their evaluation by readers.

The main purpose of artistic discourse - emotional and aesthetic impact on the recipients. Its essence reflects the dialectical connection of the following constants: writer - work of art-reader. The specificity of artistic discourse is that the interaction of the writer-addressee and the readeraddressee takes place in the text-mediated communicative space. The reader perceives the discursive activity of the writer in his own way through the mediation of the artistic text, which is one of the components of the act of artistic communication.

In particular, an important feature of the literary prose text, realized in the genres of the novel, novel, short story, etc., is the internal structural combination of the language of the author and his characters. Therefore, the "translation" of such texts into the appropriate discourse involves two plans of communication - external (sender-author $\rightarrow$ addressee-reader) and internal (character $\rightarrow$ character, and in its deep essence it is - the author $\rightarrow$ character $\rightarrow$ reader). On this basis, within the artistic discourse there are authorial and character discourses (Kolegaeva, 2010: 103) or "discursive zones of the narrator and the character" (Bekhta, 2004: 8).

Based on the definitions of the concept recorded in the works of the developers of discourse theory (Karasyk, 2002; Karasyk, 2007; Pocheptsov, 1982; Batsevich, 2006; Batsevich, 2009; Batsevich, 2011; Kondratenko, 2015; Serazhim, 2010, etc.), artistic discourse is interpreted as a communicative act that arises as a result of the writer's interaction with readers, mediated by the literary text (texts), which encodes the intentions of the addressee, deciphered by recipients using authorial linguistic means.

In modern linguo-Ukrainian studies, it is urgent to substantiate the discursive features of the works of the most famous writers, who with their highly artistic words joined not only the formation of the foundations of various literary genres, but also actively influence the formation and expansion of readers' worldviews.

Conclusions. Thus, a general review of works that highlight the problem of correlating the concepts of "text" - "discourse", suggests that at the present stage of development of linguoUkrainian studies of texts of all styles and genres requires discursive analysis, as in the language of fiction recorded authorial intentions, which must be "deciphered" by speakers in the process of dynamic cognition of semantic and semantic depths of a text, involving their own practical experience and knowledge during its decoding. We see prospects for further research of this topical problem in the study of the features of artistic discourses of classic writers and famous contemporary artists, whose language creation is organically connected with the development of the Ukrainian literary word as an important component of the linguistic and cultural universe.

\section{REFERENCES}

Aznaurova, E. S. (1988). Pragmatika hudozhestvennogo slova [Pragmatics of the artistic word]. Tashkent: Fan [in Russian].

Arutyunova, N. D. (1990). Diskurs [Discourse]. Lingvisticheskiy entsiklopedicheskiy slovar'. Yartseva, V. N. (Red.) [Linguistic encyclopedic dictionary. Yartseva, V. N. (Ed.)]. (pp. 136-137). M.: Sovetskaya entsiklopediya [in Russian].

Babenko, L. G., \& Karazin, Yu. V. (2004). Lingvisticheskij analiz hudozhestvennogo teksta [Linguistic analysis of an artistic text]. Moscow: Flinta; Nauka [in Russian].

Bacevich, F. S. (2011). Vstup do lingvistichnoyi pragmatiki [Introduction to linguistic pragmatics]. Kiyiv: VC “Akademiya” [in Ukrainian].

Bacevich, F. S. (2009). Lingvistichna pragmatika: sproba obgruntuvannya problemnogo polya i doslidnickoyi odinici [Linguistic pragmatics: an attempt to substantiate the problem field and research unit]. Movoznavstvo - Linguistics, 1, 29-37 [in Ukrainian]. 


\section{Ukrainian sense. 2020. ISSN 2313-4437}

Bacevich, F. S. (2006). Filosofsko-metologichni zasadi suchasnoyi lingvistiki: sproba obgruntuvannya [Philosophical and methodological principles of modern linguistics: an attempt to substantiate]. Movoznavstvo - Linguistics, 6, 33-40 [in Ukrainian].

Behta, I. A. (2004). Diskurs naratora v anglomovnij hudozhnij prozi [Narrator's discourse in English fiction]. Kyiv: Gramota [in Ukrainian].

Benveniste, E. (1959). Les relations de tems dans le verbe franais. Bulletin de la Socm de lingvistique de Paris, 54 (I), 235-250.

Blinova, I. A. (2011). Vzayemodiya movlennyevih form u hudozhnomu prozovomu diskursi (na materiali anglijskoyi, ukrayinskoyi ta francuzkoyi mov) [Interaction of speech forms in artistic prose discourse (on the material of English, Ukrainian and French languages)]. Extended abstract of Candidate's thesis. Doneck [in Ukrainian].

Bogdanov, V. V. (1993). Tekst i tekstovoe obshenie [Text and text communication]. SanktPeterburg: Izd-vo Sankt-Peterburgskogo gosudarstvennogo universiteta [in Russian].

Byelova, A. D. (2002). Ponyattya "stil", "zhanr", "diskurs", "tekst" u suchasnij lingvistici. Inozemna filolohiya [The concept of "style", "genre", "discourse", "text" in modern linguistics. Foreign philology]., 32-33, 7-14 [in Ukrainian].

Colin, D. V. (2016). Sintaksichni osnovi poetichnogo diskursu (na materiali yudejskoyi liturgijnoyi poeziyi aramejskoyu movoyu II-VIII st.) [Syntactic bases of poetic discourse (on the material of Jewish liturgical poetry in Aramaic language of the II-VIII centuries)]. Extended abstract of Doctor's thesis. Kyiv [in Ukrainian].

Frolova I. Ye., \& Omecinska, O. V. (2018). Specifika hudozhnogo diskursu ta jogo aspektiv. Visnyk KHNU imeni Karazina [Specifics of artistic discourse and its aspects. Bulletin of KhNU named after VN Karazin. Foreign philology]. 87, 52-59 [in Ukrainian].

Gocinec, I. L. (2010). Asociativno-semantichne pole "Chornobil" u suchasnomu ukrayinskomu hudozhnomu diskursi [Associative-semantic field "Chernobyl" in modern Ukrainian artistic discourse]. Extended abstract of Candidate's thesis. Kyiv, 19 [in Ukrainian].

Karasik, V. I. (2007). Yazykovye klyuchi [Language keys]. Volgograd: Paradigma [in Russian].

Karasik, V. I. (2002). Yazykovoj krug: lichnost, koncepty, diskurs [Language circle: personality, concepts, discourse]. Volgograd: Peremena [in Russian].

Kolegayeva, I. M. (2010). Zobrazhennya personazhnogo diskursu yak zhanrovo determinovanij vpliv komunikativnoyi vtorinnosti v hudozhnomu teksti. Visnyk KHNU imeni Karazina [The image of character discourse as a genre-determined influence of communicative secondary in the literary text. Bulletin of KhNU named after VN Karazin. Foreign philology]. 896, 102-107 [in Ukrainian].

Kondratenko, N. V. (2015). Diskursivna paradigma doslidzhen hudozhnogo tekstu. Zapysky $z$ romano-hermans'koyi filolohiyi [Discursive paradigm of research of the literary text. Notes on Romano-Germanic philology]. 60-65 [in Ukrainian].

Korolova, V. V. (2016). Komunikativno-pragmatichna organizaciya suchasnogo ukrayinskogo dramaturgijnogo diskursu [Communicative-pragmatic organization of modern Ukrainian dramatic discourse]. Dnipro: Lira [in Ukrainian].

Korolova, V. V. (2017). Suchasnij ukrayinskij dramaturgijnij diskurs: komunikativna struktura ta pragmatika [Modern Ukrainian dramatic discourse: communicative structure and pragmatics]. Doctor's thesis. Dnipro [in Ukrainian].

Kubryakova, E. S. (2004). Yazyk i znanie: Na puti polucheniya znanij o yazyke. Chasti rechi s kognitivnoj tochki zreniya. Rol yazyka v poznanii mira [Language and knowledge: On the way to gaining knowledge about language. Parts of speech from a cognitive point of view. The role of language in the knowledge of the world.] Moscow: Yazyki slavyanskoj kultury [in Russian].

Ogar, A. O. (2014). Verbalizaciya konceptiv ZEMLYa i NEBO v ukrayinskomu poetichnomu diskursi drugoyi polovini 20 st. [Verbalization of the concepts of EARTH and SKY in the Ukrainian poetic discourse of the second half of the 20th century]. Extended abstract of Candidate's thesis. Ivano-Frankivsk [in Ukrainian].

Perelomova, O. S. (2007). Koncept samotnosti yak intertekstema individualno-avtorskoyi paradigmi poetichnih tvoriv Pavla Tichini. Visnyk Zhytomyrs'koho derzhavoho universytetu imeni 


\section{Ukrainian sense. 2020. ISSN 2313-4437}

Ivana Franka [The concept of loneliness as an intertext of the individual-author paradigm of poetic works of Pavlo Tychyna. Bulletin of the Zhytomyr state Ivan Franko University]. 169-172 [in Ukrainian].

Pocheptsov, G. (1982). Mova ta humor [Language and Humor]. Kiev: Vyscha Skola [in Ukrainian].

Prihodko, A. M. (2008). Koncepti i konceptosistemi $v$ kognitivno-diskursivnij paradigmi lingvistiki [Concepts and conceptual systems in the cognitive-discursive paradigm of linguistics]. Zaporizhzhya: Prem'yer [in Russian].

Revzina, O. G. (2004). Lingvistika XXI veka: na putyah celostnosti teorii yazyka. Kritika $i$ semiotika [Linguistics of the XXI century: on the path to the integrity of the theory of language. Criticism and semiotics]. 7, 11-20 [in Russian].

Selivanova, O. O. (2008). Suchasna lingvistika: napryami ta problemi : pidruchnik [Modern linguistics: directions and problems: a textbook]. Poltava: Dovkillya-K [in Ukrainian].

Serazhim, K. (2010). Diskurs yak sociolingvalne yavishe: metodologiya, arhitektonika, variativnist [Discourse as a sociolinguistic phenomenon: methodology, architecture, variability]. Kyiv: Vidavec Palivoda A. V. [in Ukrainian].

Stepanov, Yu. S. (1997). Konstanty: Slovar russkoj kultury [Constants: Dictionary of Russian culture]. Moscow: Shkola "Yazyki russkoj kultury" [in Russian].

Zagnitko, A. P. (2008). Osnovi diskursologiyi [Fundamentals of discourse]. Doneck: DonNU [in Ukrainian].

\section{Анотація}

Постановка проблеми. Одним з основних питань лінгвоукраїністики ХX - початку XXI cm. є всебічне дослідження поняття дискурсу, щзо відбиває найрізноманітнімі реальні вияви мовного спілкування людини в тих чи тих соиіальних сферах ї̈ комунікативного простору. Актуалізація иъього поняття в різних наукових галузях, представники яких вивчають сутність і механізми взаємодї констант таких лінгвофілософських дихотомій, як “мова і суспільство”, “мова ілюдина”, спричинила потребу його чіткої дефініџії, а також розроблення типології дискурсів, визначення їхніх основних категорійних ознак та ін. Попри те, щзо мовознавиі залучають низку методик дискурсивного аналізу лінгвальних одиниць, єдиного підходу до їх вивчення в межах теорії дискурсу наразі немає.

Мета статmi - виявити й обгрунтувати особливості художнього тексту з погляду сучасної дискурсології. Основні завдання статті: визначити типологійно-категорійні ознаки художнього дискурсу, установити та описати найважливіші аспекти вивчення художніх текстів різних жанрів у межах дискурсології.

Методи дослідження. У праці використано загальнонаукові методи спостереження, аналізу, синтезу, порівняння; лінгвістичні методи, серед яких описовий метод - для витлумачення дискурсивного статусу художнього тексту; метод інтегративного аналізу, який покладено воснову комплексного дослідження сукупності різних аспектів, застосованих під час вивчення художнього тексту як утілення індивідуально-авторських комунікативних інтенцій; контекстуально-інтерпретаційний метод - для виокремлення ймовірних читаџьких стратегій рецепиії художнього тексту та його складників.

Основні результати дослідження. Поняття дискурсу в найширшому розумінні асоиіюють з усіма виявами комунікації. Дискурс є наслідком моделювання структур знань, що забезпечують стратегічне планування, перебіг і контроль комунікації, дію механізмів комунікативної компетенції, регуляцію процесів інтерактивності тощэ. Важливим комунікативно-семантичним сегментом иілісної природи аналізованого поняття $\epsilon$ його взаємодія з різними чинниками, що відбивають сутність спілкування, зокрема з поняттям тексту. На розроблення теоретичних засад категоризаиії й типологізації поняття дискурсу досі неабиякий вплив має мовознавча традииія, оскільки донедавна дискурс нерідко ототожнювали з текстом як складним лінгвальним знаком, щзо постає внаслідок процесу мовотворення. Наразі структурно-семантичні параметри тексту дослідники окреслюють 


\section{Ukrainian sense. 2020. ISSN 2313-4437}

низкою ознак, щзо так само постають актуальними ц̆ об'єктивними $i$ для дискурсу: завершеність; когерентність; иілісність; лексична, граматична, логічна, стилістична, смислова зв'язність; композиційна завершеність; комунікативна та прагматична спрямованість тощо. Диферениіація дискурсів - одне з найважливіших питань сучасної дискурсології, щзо наразі постає проблемою, яку дослідники, спираючись на широкий спектр різних суспільно-мовних виявів комунікації, вирішують не однаково. Для становлення типології дискурсів, як і текстів, потрібне розроблення єдиних критеріїв їхньої класифікаиіі та визначення основних категорій тексту й дискурсу. Художній дискурс, на відміну від інших дискурсів, передбачає опосередковане спілкування автора (адресанта) з численними читачами (адресатами). Створюючи текст, письменник прогнозує очікувану реакиію на його зміст з боку читачів, натомість “переведення" художнього тексту в дискурс адресати здійснюють по-своєму, спираючись на власні знання, досвід, відчуття та емоиії. Взаємодія автора-адресанта з численними адресатами позбавлена реальних комунікативних чинників, зокрема темпоральної та локальної фіксаиії. Попри відсутність безпосереднього контакту, комунікативний вплив письменника на читачів є вочевидь результативним: якщо митець глибоко знає мову, індивідуалізує та увиразнює лінгвальні засоби, то й викликає певне ставлення до своїх художніх текстів і їхню оцінку читачами.

Висновки $\boldsymbol{i}$ перспективи. На сучасному етапі розвитку лінгвоукраїністики дослідження текстів будь-яких стилів і жанрів потребує дискурсивного аналізу, оскільки в мові художньої літератури зафіксовано авторські інтенції, які мають "розцифровувати" мовиі в процесі динамічного пізнання семантико-змістових глибин того чи того тексту, залучаючи власний практичний досвід $i$ знання під час його декодування. Перспективи подальшого дослідження иієї актуальної проблеми вбачаємо у вивченні особливостей художніх дискурсів письменників-класиків та відомих сучасних митиів, із мовотворчістю яких органічно пов'язаний розвій украӥнського художньо-літературного слова як важливого складника лінгвокультурного універсуму.

Ключові слова: дискурс, текст, художній дискурс, художній текст, адресант, адресат.

\section{Abstract}

Background. One of the main issues of linguistics of the XX - early XXI century is a comprehensive study of the concept of discourse, which reflects a variety of real manifestations of human language communication in certain social spheres of its communicative space. The actualization of this concept in various scientific fields, the representatives of which study the essence and mechanisms of interaction of constants of such linguistic and philosophical dichotomies as "language and society", "language and man", has led to the need for its clear definition and typology of discourses etc. Despite the fact that linguists use a number of methods of discursive analysis of linguistic units, there is currently no single approach to their study within the theory of discourse.

The purpose of the article is to identify and substantiate the features of the literary text in terms of modern discourse. The main objectives of the article: to determine the typological and categorical features of artistic discourse, to establish and describe the most important aspects of the study of artistic texts of different genres within discourse.

Methods. The paper uses general scientific methods of observation, analysis, synthesis, comparison; linguistic methods, including the descriptive method - to interpret the discursive status of the literary text; the method of integrative analysis, which is the basis of a comprehensive study of a set of different aspects used in the study of the literary text as the embodiment of individualauthorial communicative intentions; the contextual-interpretive method - to identify probable reading strategies of reception of the literary text and its components.

Results. The concept of discourse in the broadest sense is associated with all manifestations of communication. Discourse is a consequence of modeling knowledge structures that provide strategic planning, flow and control of communication, the operation of mechanisms of 


\section{Ukrainian sense. 2020. ISSN 2313-4437}

communicative competence, regulation of interactivity processes and more. An important communicative-semantic segment of the holistic nature of the analyzed concept is its interaction with various factors that reflect the essence of communication, in particular with the concept of the text. The linguistic tradition still has a great influence on the development of theoretical principles of categorization and typology of the concept of discourse, because until recently the discourse was often identified with the text as a complex linguistic sign that arises as a result of the process of language formation. Currently, researchers outline the structural and semantic parameters of the text with a number of features that also appear relevant and objective for the discourse: completeness; coherence; integrity; lexical, grammatical, logical, stylistic, semantic coherence; compositional completeness; communicative and pragmatic orientation, etc. Differentiation of discourses is one of the most important issues of modern discourse, which is currently a problem that researchers, based on a wide range of different socio-linguistic manifestations of communication, solve differently. To establish a typology of discourses, as well as texts, it is necessary to develop common criteria for their classification and determine the main categories of text and discourse. Artistic discourse, in contrast to other discourses, involves indirect communication of the author (sender) with numerous readers (addressees). When creating a text, the writer predicts the expected reaction to its content from readers, instead of "translating" the literary text into the discourse, the recipients carry out in their own way, based on their own knowledge, experience, feelings and emotions. The interaction of the addressee author with numerous addressees is devoid of real communicative factors, in particular temporal and local fixation. Despite the lack of direct contact, the writer's communicative influence on readers is obviously effective: if the artist has a deep knowledge of the language, individualizes and emphasizes linguistic means, it evokes a certain attitude to his literary texts and their evaluation by readers.

Discussion. At the present stage of development of texts of any styles and genres requires discursive analysis, because in the language of fiction recorded authorial intentions that should "decipher" speakers in the process of dynamic cognition of semantic and semantic depths of a text, involving their own practical experience and knowledge during its decoding. We see prospects for further research of this topical problem in the study of features of artistic discourses of classic writers and famous contemporary artists, whose language creation is organically connected with the development of the Ukrainian literary word as an important component of the linguistic and cultural universe.

Keywords: discourse, text, artistic discourse, artistic text, sender, addressee. 